\title{
HUBUNGAN KOMPLEMENTER ANTARA MANAJEMEN PUNCAK PEREMPUAN DAN LITERASI KEUANGAN TERHADAP EARNINGS MANAGEMENT PADA PERUSAHAAN YANG TERDAFTAR DI BEI PERIODE 2015
}

\author{
Brenda Astrid Tamara \\ Universitas Surabaya \\ brendatamara27@gmail.com \\ Yie Ke Feliana \\ Universitas Surabaya \\ yiekefeliana@staff.ubaya.ac.id
}

\begin{abstract}
The purpose of this study is to examine whether the presence of female top management and female top management with financial literacy has an impact on reducing earnings management. Earnings management is proxied by discretionary accruals and measured using the Modified Jones (1995) model on a cross-sectional version. The study population use all company that has been listed in Bursa Efek Indonesia (BEI) at 2015. The amount of company used in this study are 291 companies. The results of this study shows that there is no effect between female top management and female top management with financial literacy on the reduction of earnings management.
\end{abstract}

Keywords: Gender; Financial literacy; Earnings Management; Top management; Good Corporate Governance

\section{PENDAHULUAN}

Di zaman yang semakin berkembang ini, kesetaraan gender bukan hal yang menjadi masalah. Perempuan yang dulunya hanya dianggap sebagai ibu rumah tangga yang pasif dan tidak dapat berkarir sekarang dapat dipekerjakan oleh perusahaan. Perempuan sekarang dapat menempuh pendidikan yang layak dan dapat mengisi jabatan-jabatan yang penting dalam organisasi atau badan usaha seperti menduduki jabataan manajemen puncak.

Berdasarkan Kompas.com (18 November 2017) Dong Minzhu yang baru saja masuk ke dalam 100 perempuan paling sukses menurut Forbes. Dong Minzu saat ini merupakan pemimpin di perusahaan AC Gree yang kini memiliki nilai 22 milliar dollar AS atau sekitar Rp.292,6 triliun. Di Indonesia sendiri sudah terdapat beberapa perempuan yang menjadi CEO/Direktur perusahaan seperti: Catherine Hindra Sutjahyo (direktur Zalora), , Grace Tahir (Direktur Rumah Sakit Mayapada),Veronica Linardi (co-founder Qerja), Diajeng Lestari 
Hubungan Komplementer Antara Manajemen Puncak Perempuan Dan Literasi Keuangan Tehadap Earnings Management Pada Perusahaan Yang Terdaftar Di BEI Periode 2015

(Founder HijUp), dan Dian Siswarini (CEO PT.XL Axiata). Ini menunjukkan semakin terbukanya pandangan dunia terhadap perempuan yang duduk di manajemen puncak.

Menurut Dieleman dan Aishwarya (2012) persentase perempuan yang duduk dalam dewan komisaris dan dewan direksi dalam perusahaan yang terdaftar di Bursa Efek Indonesia adalah $11.6 \%, 84.4 \%$ lainnya diduki oleh laki-laki. Jumlah ini lebih rendah dibandingkan dengan Eropa (17\%), Amerika Utara 16.1\%, dan Australia (13.8\%). Ini menunjukkan masih terdapat efek glass ceiling yang membatasi perempuan untuk maju dalam posisi-posisi pemimpin seperti menjadi dewan direksi maupun dewan komisaris pada tahun 2012.

Namun saat ini pemimpin perempuan di Indonesia bukanlah sesuatu yang tidak wajar, hal ini didukung dengan data yang menunjukkan persentase pemimpin perempuan Indonesia sebesar 46\% yang merupakan persentase terbesar di Asia Pasifik dan terbesar nomor 2 di dunia (Grant Thorton: 2017). Menurut Dieleman dan Aishwarya (2012) 34\% posisi dewan di Indonesia diduduki oleh satu perempuan, 14.4\% posisi dewan diduduki oleh dua perempuan, $8.7 \%$ posisi dewan diduki oleh tiga perempuan, dan $2.8 \%$ posisi dewan diduduki oleh lebih dari 4 perempuan atau lebih. Menurut Dieleman et al (2015) 35\% posisi dewan di Indonesia diduduki oleh satu perempuan, 9\% posisi dewan diduduki oleh dua perempuan, $16 \%$ posisi dewan diduki oleh tiga perempuan, dan $6 \%$ posisi dewan diduduki oleh lebih dari 4 perempuan atau lebih. Persentase pemimpin perempuan yang meningkat dari tahun 2012 ke 2015 dan meningkatnya persentase posisi dewan perempuan menunjukkan semakin terbukanya Indonesia pada perempuan yang duduk di manajemen puncak.

Menurut Fondas dan Sassalos (2000) direktur perempuan meningkatkan fungsi dan efisiensi dewan demikian juga kinerja perusahaaan dan kualitas pendapatan karena perempuan memberikan perspektif dan opini yang berbeda dalam rapat dewan. Perempuan memiliki pengalaman yang berbeda dari pada laki-laki karena perbedaan proses sosialisasi (Ambrose dan Schminke, 1999; Hilman et al, 2007) atau direktur perempuan cenderung lebih mempersiapkan untuk pertemuan dewan dari pada laki-laki (Adams dan Ferreira, 2009). Perempuan melengkapi laki-laki dalam manajemen dan memberikan keseimbangan yang sehat kepada perusahaan (Malch Pines, 1989; Morrison et al, 2004 dalam Gavious et al, 2016). 
Hubungan Komplementer Antara Manajemen Puncak Perempuan Dan Literasi Keuangan Tehadap Earnings Management Pada Perusahaan Yang Terdaftar Di BEI Periode 2015

Kehadiran perempuan dalam dewan direksi meningkatkan fungsi dan efisiensi dewan (Adams dan Ferreira, 2009; Fondas dan Sassalos, 2000; Hillman, Shropshire, dan Canella, 2007). Penelitian selanjutnya memberikan bukti bahwa direksi perempuan mencegah atau memperbaiki perilaku oportunis seperti earnings management. Bersamaan dengan hal tersebut, direktur dengan literasi keuangan dan berpengalaman lebih mudah untuk mendeteksi dan membatasi earnings management (Gavious et al, 2011). Namun hasil penelitian dari Abdullah dan Ismail (2016) menemukan bahwa kehadiran perempuan dalam dewan atau komite audit tidak berhubungan dalam membatasi earnings management.

Adanya perbedaan hasil penelitian terdahulu dan penelitian terdahulu yang menghubungkan jenis kelamin manajemen puncak, literasi keuangan, dan earnings management masih sangat terbatas. Menyebabkan perlu dilaksanakannya studi lanjutan untuk menguji pengaruh manajemen puncak perempuan yang literasi keuangan dalam suatu badan usaha terhadap mengurangi earnings management. Oleh karena itu penelitian ini ingin untuk mengetahui pengaruh dari manajemen puncak perempuan dan manajemen puncak perempuan yang literasi keuangan dalam dewan suatu badan usaha terhadap pengurangan earnings management.

\section{TELAAH TEORETIS}

\section{Hubungan Manajemen Puncak Perempuan Dengan Earnings Management}

Menurut KNKG (2006) kepengurusan perseroan terbatas di Indonesia menganut system dua badan (two tier board system) yaitu Dewan Komisaris dan Dewan Direksi yang memiliki kewajiban dan tanggung jawab yang jelas sesuai dengan fungsinya masing-masing. Oleh karena itu dalam penelitian ini manajemen puncak perempuan dibagi menjadi tiga yaitu: dewan direksi, dewan komisaris, dan komite audit. Pemilihan tiga posisi tersebut karena tiga posisi tersebut memiliki peran yang berbeda-beda namun merupakan manajemen puncak dalam perusahaan. Dewan direksi bertanggung jawab untuk kegiatan operasional sedangkan dewan komisaris bertugas untuk mengawasi direksi. Komite audit bertugas untuk membantu dewan komisaris dimana ketua dari komite audit biasanya berasal dari komisaris independen.

Menurut Fondas dan Sassalos (2000) direktur perempuan meningkatkan fungsi dan efisiensi dewan demikian juga kinerja perusahaaan dan kualitas pendapatan karena 
perempuan memberikan perspektif dan opini yang berbeda dalam rapat dewan. Perempuan memiliki pengalaman yang berbeda dari pada laki-laki karena perbedaan proses sosialisasi (Ambrose dan Schminke, 1999; Hilman et al, 2007) atau direktur perempuan cenderung lebih mempersiapkan untuk pertemuan dewan dari pada laki-laki (Adams dan Ferreira, 2009).

Menurut Huse dan Solberg (2006) direktur perempuan meningkatkan pengambilan keputusan, perilaku, dan efektivitas dewan. Penelitian selanjutnya memberikan bukti bahwa direksi perempuan mencegah atau memperbaiki perilaku oportunis seperti earnings management. Kehadiran perempuan dalam Board of Director begitu pula dengan komite audit berhubungan dalam mengurangi earnings management (Chen dan Gavious 2016; Gavious et al, 2011).

Namun penelitian Abdullah dan Ismail (2016) menunjukkan kehadiran perempuan dalam dewan dan komite audit tidak dapat mengurangi earnings management. Meskipun perempuan lebih etis dari pada laki-laki, perempuan mungkin tidak dapat mempengaruhi rekan laki-laki dalam masalah earnings management (Sun et al (2011) dalam Abdullah dan Ismail (2016).

\section{$\mathrm{H}_{1}$ : Kehadiran manajemen puncak perempuan akan berpengaruh negatif terhadap earnings management. \\ $\mathrm{H}_{1 \mathrm{a}}$ : Kehadiran Women Board Director akan berpengaruh negatif terhadap earnings management \\ $\mathrm{H}_{1 \mathrm{~b}}$ : Kehadiran Women Board Commisioner akan berpengaruh negatif terhadap earnings management. \\ $\mathrm{H}_{1 \mathrm{c}}$ : Kehadiran Women Audit Committee akan berpengaruh negatif terhadap earnings management.}

\section{Hubungan Manajemen Puncak Perempuan Yang Literasi Keuangan Dengan Earnings Management}

Menurut Huston (2011: 115) "literasi keuangan adalah seberapa baik seseorang dapat mengerti dan menggunakan informasi keuangan personal.” Dalam penelitian ini manajemen puncak dengan literasi keuangan adalah orang yang duduk di manajemen puncak yang memiliki pendidikan atau latar belakang seperti: sarjana ekonomi, dan atau master akuntansi dan atau keuangan, CPA, dan atau jabatan saat ini atau pernah menjabat sebagai eksekutif 
Hubungan Komplementer Antara Manajemen Puncak Perempuan Dan Literasi Keuangan Tehadap Earnings Management Pada Perusahaan Yang Terdaftar Di BEI Periode 2015

dalam lembaga keuangan. Hal ini sesuai dengan penelitian Xie et al (2003) dengan penyesuaian kondisi di Indonesia.

Menurut Gavious et al (2011) direktur laki-laki dan perempuan tidak secara penting membedakan dalam kemampuan untuk mendeteksi earnings management, kemampuan untuk mendeteksi penyimpangan akuntansi secara umum lebih dipengaruhi oleh latar belakang keuangan. Bersamaan dengan hal tersebut, direktur dengan literasi keuangan dan berpengalaman lebih mudah untuk mendeteksi dan membatasi earnings management (Xie et al, 2003; Zechman, 2012).

Menurut Chen dan Gavious (2016) kehadiran direktur perempuan bermanfaat dalam fungsi Board of Director secara umum, namun belum cukup untuk mengawasi agresivitas akuntansi jika perempuan tidak literasi keuangan. Kehadiran manajemen puncak perempuan yang literasi keuangan secara signifikan dapat menurunkan earnings management.

\section{METODE}

Sifat dari penelitian ini yaitu hypothesis testing karena dalam penelitian ini menguji apakah terdapat pengaruh manajemen puncak perempuan dan manajemen puncak perempuan yang literasi keuangan terhadap pengurangan Earnings Management. Penelitian ini memakai data sekunder yaitu berupa laporan tahunan (annual report) semua perusahaan kecuali sektor keuangan pada periode 2015 yang diperoleh melalui website Bursa Efek Indonesia (www.idx.co.id). Populasi dalam penelitian ini merupakan seluruh perusahaan kecuali sektor keuangan yang telah go public dan tercatat di Bursa Efek Indonesia (BEI). Dalam penelitian ini, pengambilan sampel menggunakan teknik non probability sampling dengan menggunakan metode purposive sampling yaitu mengambil sampel yang sesuai dengan kriteria yang telah terlebih dahulu ditetapkan oleh peneliti sehingga relevan dengan tujuan penelitian.

\section{Variabel dan definisi operasional variabel}

\section{Variabel dependen}

- Earning management adalah pilihan manajer terhadap kebijakan akuntansi atau tindakan nyata yang akan mempengaruhi pendapatan untuk mencapai tujuan pelaporan tertentu. Earning management ditunjukkan dengan discretionary accruals yang diukur 
Hubungan Komplementer Antara Manajemen Puncak Perempuan Dan Literasi Keuangan Tehadap Earnings Management Pada Perusahaan Yang Terdaftar Di BEI Periode 2015

menggunakan model Modified Jones (m-J) pada basis cross-sectional sesuai dengan Dechow et al (1995).

- $\quad$ Total accruals (TA) dapat dihitung dengan menggunakan rumus sebagai berikut:

$$
\frac{\mathrm{TA} \mathrm{A}_{\mathrm{i}, \mathrm{t}}}{\mathrm{A}_{\mathrm{i},-1}}=\beta_{1}\left(\frac{1}{\mathrm{~A}_{\mathrm{i}, \mathrm{t}-1}}\right)+\beta_{2}\left(\frac{\Delta \mathrm{REV}_{\mathrm{i}, \mathrm{t}}}{\mathrm{A}_{\mathrm{i}, \mathrm{t}-1}}\right)+\beta_{3}\left(\frac{\mathrm{PPE}_{\mathrm{i}, \mathrm{t}}}{\mathrm{A}_{\mathrm{i},-1}}\right)+\beta_{4} R O A+\beta_{5}\left(\frac{\text { ExFin }}{\mathrm{A}_{\mathrm{i}, \mathrm{t}-1}}\right)+\beta_{6} A g e+\beta_{7} B M+\varepsilon \mathrm{i}, \mathrm{t}
$$

- $\quad$ Abnormal (discretionary) accruals dapat dihitung dengan menggunakan rumus sebagai berikut:

$$
\mathrm{AA}=\frac{\mathrm{TA} \mathrm{A}_{\mathrm{i}, \mathrm{t}}}{\mathrm{A}_{\mathrm{i},-1}}-\left[\widehat{\beta}_{1}\left(\frac{1}{\mathrm{~A}_{\mathrm{i},-1}}\right)+\widehat{\beta}_{2}\left(\frac{\Delta \mathrm{REV}_{\mathrm{i}, t-}-\Delta \mathrm{REC}_{\mathrm{i}, \mathrm{t}}}{\mathrm{A}_{\mathrm{i}, \mathrm{t}-1}}\right)+\widehat{\beta}_{3}\left(\frac{\mathrm{PPE}_{\mathrm{i}, \mathrm{t}}}{\mathrm{A}_{\mathrm{i},-1}}\right)+\widehat{\beta}_{4} R O A+\widehat{\beta}_{5}\left(\frac{\text { ExFin }}{\mathrm{A}_{\mathrm{i}, \mathrm{t}-1}}\right)+\widehat{\beta}_{6} A g e+\widehat{\beta}_{7} B M\right]
$$

$\mathrm{TA}_{\mathrm{i}, \mathrm{t}}=$ Total accruals pada perusahaan i untuk tahun t,didefinisikan sebagai laba sebelum pos luar biasa dikurangi arus kas operasi; $\mathrm{AA}=$ Abnormal accruals; $\Delta \mathrm{REV}_{\mathrm{i}, \mathrm{t}}=$ Perubahan revenue pada perusahaan $\mathrm{i}$ untuk tahun $\mathrm{t} ; \Delta \mathrm{REC}_{\mathrm{i}, \mathrm{t}}=$ Perubahan receivables perusahaan $\mathrm{i}$ untuk tahun $\mathrm{t}$; $\mathrm{A}_{\mathrm{i}, \mathrm{t}-1}=$ Total aset perusahaan pada awal tahun $\mathrm{t}$; $\mathrm{PPE}_{\mathrm{i}, \mathrm{t}}=$ Aktiva tetap (Gross level property, plant, dan equipment) pada perusahaan i untuk tahun $\mathrm{t} ; \hat{\beta}_{1}, \hat{\beta}_{2}, \hat{\beta}_{3}=$ Estimasi regresi OLS dari koefisien regresi $\beta_{1}, \beta_{2}$, dan $\beta_{3} ; \widehat{\beta}_{4}, \widehat{\beta}_{5}, \widehat{\beta}_{6}, \widehat{\beta}_{7}=$ Estimasi regresi OLS dari koefisien regresi $\beta_{4}$, $\beta_{5}, \beta_{6}$ dan $\beta_{7} ; \varepsilon_{\mathrm{i}, \mathrm{t}}=$ Error; ROA=laba sebelum extraordinary item diukur menggunakan lagged total asset.; EXFin=pendanaan eksternal bersih yang diukur dengan menjumlahkan kas bersih yang diterima dari pemegang utang; Age=jumlah tahun sejak pendaftaran IPO; $\mathrm{BM}=$ rasio dari aset total ke aset total dikurangi nilai buku dari ekuitas ditambah nilai pasar dari ekuitas.

\section{Variabel independen}

- Woman Board Director (WBD) yang merupakan dummy variable yaitu pada dewan direksi perusahaan angka 1 menunjukkan terdapat dewan direksi perempuan dalam perusahaan, dan angka 0 menunjukkan tidak terdapat dewan direksi perempuan dalam perusahaan.

- Woman Board Commisioner (WBC) yang merupakan dummy variable yaitu pada dewan komisarisi perusahaan angka 1 menunjukkan terdapat dewan komisaris perempuan dalam perusahaan, dan angka 0 menunjukkan tidak terdapat dewan komisaris perempuan dalam perusahaan. 
Hubungan Komplementer Antara Manajemen Puncak Perempuan Dan Literasi Keuangan Tehadap Earnings Management Pada Perusahaan Yang Terdaftar Di BEI Periode 2015

- Woman Audit Committee (WAC) yang merupakan dummy variable yaitu pada komite audit perusahaan angka 1 menunjukkan terdapat komite audit perempuan dalam perusahaan, dan angka 0 menunjukkan tidak terdapat komite audit perempuan dalam perusahaan.

- Woman Board Director Financial Literacy (WBDFL) yang merupakan dummy variable yaitu pada dewan direksi perusahaan angka 1 menunjukkan terdapat dewan direksi perempuan yang literasi keuangan dalam perusahaan, dan angka 0 menunjukkan tidak terdapat dewan direksi perempuan yang literasi keuangan dalam perusahaan.

- Woman Board Commisioner Financial Literacy (WBCFL) yang merupakan dummy variable yaitu pada dewan komisaris perusahaan angka 1 menunjukkan terdapat dewan komisaris perempuan yang literasi keuangan dalam perusahaan, dan angka 0 menunjukkan tidak terdapat dewan komisaris perempuan yang literasi keuangan dalam perusahaan.

- Woman Audit Committee Financial Literacy (WACFL) yang merupakan dummy variable yaitu pada komite audit perusahaan angka 1 menunjukkan terdapat komite audit perempuan yang literasi keuangan dalam perusahaan, dan angka 0 menunjukkan tidak terdapat komite audit perempuan yang literasi keuangan dalam perusahaan.

- Jumlah perempuan sebanyak satu orang dalam dewan yang pendapatnya cenderung diabaikan sehingga sangat sulit untuk mempengaruhi keputusan merupakan penelitian yang dilakukan oleh Konrad (2008) di Amerika pada 50 perempuan yang menjadi Fortune 1000 director, sampai saat ini belum ada penelitian tersebut di Indonesia. Sehingga penelitian ini tidak menggunakan jumlah perempuan yang duduk dalam dewan melainkan kehadiran perempuan dalam dewan dan komite audit menggunakan variabel dummy yang standar sesuai dengan kenyataan yang ada pada data.

\section{Variabel kontrol}

- BIG4 yang menggunakan dummy variable yaitu pada kantor akuntan publik yang mengaudit perusahaan, angka 1 menunjukkan perusahaan diaudit oleh BIG4 dan angka 0 menujukkan perusahaan tidak diaudit oleh BIG4.

- $\quad$ Leverage yang merupakan rasio dari jumlah utang dikurangi utang lancar dibagi jumlah aset.

Jurnal Akuntansi dan Teknologi informasi (JATI) Vol. 13 Tahun 2019 
Hubungan Komplementer Antara Manajemen Puncak Perempuan Dan Literasi Keuangan Tehadap Earnings Management Pada Perusahaan Yang Terdaftar Di BEI Periode 2015

- Size diukur menggunakan log dari jumlah aset perusahaan.

- Growth merupakan perubahan persentase dalam penjualan tahunan

\section{Data dan pemilihan sampel}

Obyek yang dipakai di dalam penelitian ini merupakan semua perusahaan kecuali sektor keuangan yang telah go public dan tercatat di Bursa Efek Indonesia (BEI) pada tahun 2015. Obyek yang dipakai juga harus telah mengungkapkan profil jajaran serta latar belakang pendidikan dan atau pengalaman bekerja dari direksi, komisaris, dan komite audit selama tahun 2015. Total dari semua perusahaan kecuali sektor keuangan yang telah go public dan tercatat di Bursa Efek Indonesia (BEI) pada tahun 2015 adalah sebanyak 401 perusahaan. Dari populasi yang ada akan diseleksi dengan kriteria utama perusahaan tersebut harus menampilkan profil jajaran serta latar belakang pendidikan dan atau pengalaman bekerja dari direksi, komisaris, dan komite audit selama tahun 2015 dan meggunakan mata uang rupiah dalam laporan keuangannya. Berikut ini merupakan tabel seleksi sampel yang akan menampilkan sampel akhir yang dipakai dalam penelitian ini yang sesuai dengan kriteria sampel.

\section{Tabel 1.KRITERIAPENGAMBILANSAMPEL}

\begin{tabular}{|c|c|}
\hline Kriteria Sampel & Jumlah \\
\hline $\begin{array}{l}\text { Semua perusahaan kecuali sektor keuangan yang telah go } \\
\text { public dan tercatat di Bursa Efek Indonesia (BEI) pada } \\
\text { tahun } 2015\end{array}$ & 401 \\
\hline $\begin{array}{l}\text { Perusahaan yang tidak menggunakan mata uang rupiah } \\
\text { dalam laporan keuangannya }\end{array}$ & (77) \\
\hline $\begin{array}{l}\text { Perusahaan yang tidak mengungkapkan profil jajaran serta } \\
\text { latar belakang pendidikan dan atau pengalaman bekerja dari } \\
\text { direksi, komisaris, dan komite audit selama tahun } 2015\end{array}$ & (4) \\
\hline $\begin{array}{l}\text { Perusahaan yang tidak memiliki data laporan keuangan } \\
\text { dalam BEI }\end{array}$ & (3) \\
\hline $\begin{array}{l}\text { Perusahaan yang tidak memiliki data current liabilities } \\
\text { dalam laporan keuangannya }\end{array}$ & (1) \\
\hline
\end{tabular}

Jurnal Akuntansi dan Teknologi informasi (JATI) Vol. 13 Tahun 2019 


\begin{tabular}{l}
\hline Sampel yang merupakan outlier dan dihapus menggunakan \\
metode Box Plot 1 \\
Sampel yang merupakan outlier dan dihapus menggunakan \\
metode Box Plot 2 \\
Total perusahaan yang menjadi sampel penelitian
\end{tabular}

\section{Model regresi}

Untuk membuktikan hipotesis penelitian maka dilakukan permodelan sebagai berikut:

$$
\begin{aligned}
& \mathrm{H}_{1 \mathrm{a}}: \beta_{1}<0 ; \mathrm{H}_{1 \mathrm{~b}}: \beta_{2}<0 ; \mathrm{H}_{1 \mathrm{c}}: \beta_{3}<0 \\
& \mathrm{H}_{2 \mathrm{a}}: \beta_{5}<0 ; \mathrm{H}_{2 \mathrm{~b}}: \beta_{6}<0 ; \mathrm{H}_{2 \mathrm{c}}: \beta_{7}<0
\end{aligned}
$$

Model regresi yang dipakai untuk menguji hipotesis penelitian ini adalah sebagai berikut:

$$
\begin{aligned}
& \mathrm{EM}=\beta_{0}+\beta_{1} . \mathrm{WBD}+\beta_{2} . \mathrm{WBC}+\beta_{3} . \mathrm{WAC}+\beta_{4} . \mathrm{WBDFL}+\beta_{5} . \mathrm{WBCFL}+\beta_{6} . \\
& \mathrm{WACFL}+\beta_{7} . \mathrm{BIG} 4+\beta_{8 .} . \mathrm{LEV}+\beta_{9} . \mathrm{SIZE}+\beta_{10 .} . \mathrm{GROWTH}+\varepsilon
\end{aligned}
$$

\section{HASIL}

Tabel 2. STATISTIKFREKUENSI

\begin{tabular}{ccccccc}
\hline & WBD & WBC & WAC & WBDFL & WBCFL & WACFL \\
\hline 0 & $56.4 \%$ & $61.9 \%$ & $58.8 \%$ & $65.6 \%$ & $73.2 \%$ & $64.6 \%$ \\
1 & $43.6 \%$ & $38.1 \%$ & $41.2 \%$ & $34.4 \%$ & $26.8 \%$ & $35.4 \%$ \\
Total & $100 \%$ & $100 \%$ & $100 \%$ & $100 \%$ & $100 \%$ & $100 \%$ \\
\hline
\end{tabular}

Dari tabel statistik frekuensi diatas dapat dilihat yang memiliki paling banyak perempuan adalah posisi dewan direksi dan yang memiliki paling sedikit perempuan adalah posisi dewan komisaris. Sedangkan posisi yang memiliki paling banyak perempuan yang

\begin{tabular}{|c|c|c|c|c|c|}
\hline & \multirow{2}{*}{ Model } & \multicolumn{2}{|c|}{ Unstandardized Coefficients } & \multirow[t]{2}{*}{$\mathrm{t}$} & \multirow[t]{2}{*}{ Sig. } \\
\hline & & $\mathrm{B}$ & & & \\
\hline \multirow[t]{2}{*}{1} & (Constant) & & -.107 & -1.502 & .134 \\
\hline & WBD & & -.001 & -.072 & .942 \\
\hline
\end{tabular}
literasi keuangan adalah posisi komite audit dan yang memiliki paling sedikit perempuan yang literasi keuangan adalah posisi dewan komisaris.

Tabel 3. HASILUJIREGRESILINIERBERGANDAPADAABNORMALACCRUAL 
Hubungan Komplementer Antara Manajemen Puncak Perempuan Dan Literasi Keuangan Tehadap Earnings Management Pada Perusahaan Yang Terdaftar Di BEI Periode 2015

\begin{tabular}{lrrr} 
WBC & .003 & .205 & .838 \\
WAC & -.014 & -.849 & .396 \\
WBDFL & -.010 & -.733 & .464 \\
WBCFL & .012 & .925 & .356 \\
WACFL & .013 & .743 & .458 \\
BIG4 & -.013 & -1.429 & .154 \\
LEV & .028 & 1.863 & .063 \\
SIZE & .004 & .711 & .477 \\
GROWTH & .000069 & 1.068 & .286 \\
\hline
\end{tabular}

a. Dependent Variable: AA

Dari hasil pengujian regresi linier pada tabel 3 diperoleh model persamaan regresi sebagai berikut:

$$
\begin{aligned}
\mathrm{AA}= & -0.107-0.001 \mathrm{WBD}+0.003 . \mathrm{WBC}-0.014 \mathrm{WAC}-0.010 . \mathrm{WBDFL}+ \\
& \text { 0.012.WBCFL }+0.013 \mathrm{WACFL}-0.013 \mathrm{BIG} 4+0.028 \mathrm{LEV}+0.004 \mathrm{SIZE} \\
& +0.000069 \mathrm{GROWTH}+\varepsilon
\end{aligned}
$$

Pada tabel 3 diatas dapat dilihat bahwa konstanta dalam regresi berganda sebesar -0.107 konstanta ini merupakan nilai intercept yang terjadi ketika nilai WBD, WBC, WAC, WBDFL, WBCFL, WACFL, BIG4, LEV, SIZE, GROWTH menunjukkan nilai 0 maka AA yang dihasilkan sebesar -0.107.

\begin{tabular}{|c|c|c|c|c|c|c|}
\hline & \multirow[b]{2}{*}{ Model } & \multicolumn{2}{|c|}{ Unstandardized Coefficients } & \multirow{2}{*}{$\begin{array}{c}\text { Standardized } \\
\text { Coefficients } \\
\text { Beta } \\
\end{array}$} & \multirow[b]{2}{*}{$\mathrm{T}$} & \multirow[b]{2}{*}{ Sig. } \\
\hline & & $\mathrm{B}$ & Std. Error & & & \\
\hline \multirow[t]{7}{*}{1} & (Constant) & -.152 & .075 & & -2.026 & .044 \\
\hline & WD & -.008 & .015 & -.052 & -.546 & .586 \\
\hline & WDFL & .006 & .014 & .038 & .403 & .687 \\
\hline & BIG4 & -.020 & .010 & -.134 & -2.075 & .039 \\
\hline & LEV & .033 & .016 & .118 & 2.050 & .041 \\
\hline & SIZE & .008 & .006 & .082 & 1.278 & .202 \\
\hline & GROWTH & $9.929 E-5$ & .000 & .083 & 1.440 & .151 \\
\hline
\end{tabular}

Tabel 4.

PENGUJIANREGRESIKEMBALIDENGANVARIABELGABUNGAN

a. Dependent Variable: AA

\section{PEMBAHASAN}

Penelitian ini dilakukan untuk menguji hipotesis apakah terdapat pengaruh manajemen puncak perempuan dan manajemen puncak perempuan yang literasi keuangan 
Hubungan Komplementer Antara Manajemen Puncak Perempuan Dan Literasi Keuangan Tehadap Earnings Management Pada Perusahaan Yang Terdaftar Di BEI Periode 2015

terhadap pengurangan earnings management. Hasil persamaan regresi linier untuk menguji hipotesis penelitian menunjukkan terdapat pengaruh yang tidak signifikan antara variabel independen dengan variabel dependen.

Variabel WBD, WBC, dan WAC mempunyai tingkat signifikansi diatas 0.05 sehingga dapat dikatakan bahwa hipotesis $1(1 \mathrm{a}, 1 \mathrm{~b}, 1 \mathrm{c})$ ditolak. Hal ini sejalan dengan penelitian Abdullah dan Ismail (2016) yang mengatakan kehadiran perempuan dalam dewan dan komite audit tidak dapat mengurangi earnings management. Hal ini disebabkan karena seperti yang dikatakan oleh Sun et all (2011) dalam Abdullah dan Ismail (2016) meskipun perempuan lebih etis dari pada laki-laki, perempuan mungkin tidak dapat mempengaruhi rekan laki-laki dalam masalah earnings management. Ini dapat disebabkan oleh kurangnya jumlah dari perempuan yang duduk dalam dewan sehingga pendapat perempuan tidak mampu mempengaruhi pengambilan putusan. Kemungkinan ini dapat terjadi jika jumlah perempuan dalam dewan komisaris/direksi hanya satu sebagaimana dinyatakan oleh Konrad et al. (2008). Menurut Dieleman dan Aishwarya (2012) 34\% posisi dewan di Indonesia diduduki oleh satu perempuan, $14.4 \%$ posisi dewan diduduki oleh dua perempuan, $8.7 \%$ posisi dewan diduki oleh tiga perempuan, dan $2.8 \%$ posisi dewan diduduki oleh lebih dari 4 perempuan atau lebih.

Variabel WBDFL, WBCFL, dan WACFL mempunyai tingkat signifikansi diatas 0.05 sehingga dapat dikatakan bahwa hipotesis 2 (2a, 2b, 2c) ditolak. Hal ini tidak sejalan dengan penelitian Chen dan Gavious (2016) yang mengatakan kehadiran direktur perempuan yang literasi keuangan secara signifikan dapat menurunkan earnings management. Hal ini disebabkan karena masih sedikitnya jumlah manajemen puncak perempuan yang literasi keuangan dalam dewan sehingga tidak dapat memberikan pengaruh terhadap earnings management yang dibuktikan dalam data penelitian dimana persentase $\mathrm{WBD}, \mathrm{WBC}$, dan WAC adalah sebesar $38.1 \%, 38.2 \%$, dan $41.2 \%$, kemudian dari data sampel yang tersedia persentase WBDFL, WBCFL, dan WACFL adalah sebesar 34.4\%, 26.8\%, dan 31.3\%. Menurut Dieleman dan Aishwarya (2012) 32\% perempuan yang duduk dalam dewan pada perusahaan yang terdaftar di Bursa Efek Indonesia (BEI) mempunyai latar belakang pendidikan business administration dan $13 \%$ perempuan mempunyai latar belakang pendidikan accounting. Hal ini semakin menujukkan sangat sedikitnya manajemen puncak perempuan yang literasi keuangan. 
Hubungan Komplementer Antara Manajemen Puncak Perempuan Dan Literasi Keuangan Tehadap Earnings Management Pada Perusahaan Yang Terdaftar Di BEI Periode 2015

Variabel kontrol BIG4 terbukti tidak dapat berpengaruh signifikan terhadap AA yaitu dengan mempunyai tingkat signifikansi sebesar 0.154 yang melebihi 0.05 . Hasil pengujian ini sejalan dengan Luhgiatno (2010) big4 belum mampu mengatasi earnings management. Hal ini mungkin terjadi karena perusahaan mempunyai keinginan agar kinerja perusahaan bagus namun di mata calon investor namun mengabaikan keberadaan big4. Selain itu, keberadaan big4 bukan untuk mengatasi manajemen laba tetapi cenderung kepada peningkatan kredibilitas laporan keuangan dengan mengurangi gangguan yang ada didalamnya agar dapat menghasilkan laporan keuangan yang lebih handal (Cahyonowati, 2006 dalam Luhgiatno, 2010).

Variabel kontrol SIZE terbukti tidak dapat berpengaruh signifikan terhadap AA yaitu dengan mempunyai tingkat signifikansi sebesar 0.478 yang melebihi 0.05 . Hasil pengujian ini sejalan dengan Abdullah dan Ismail (2016) yang mengatakan size tidak berhubungan dengan earnings management. Hal ini disebabkan mungkin karena perusahaan besar suka menjadi minat dari analis keuangan dan komunitas bisnis. Oleh karena itu dalam rangka untuk mempertahankan reputasinya, perusahaan besar lebih cenderung menggunakan incomeincreasing sebagai cara untuk meratakan pendapatannya, dan menggukan income decreasing untuk mengurangi visibilitasnya (political cost). Hasilnya, income increasing dan income decreasing akan mengurangi satu sama lain, sehingga menghasilkan hasil yang tidak signifikan.

Variabel kontrol LEVERAGE terbukti tidak dapat berpengaruh signifikan terhadap AA yaitu dengan mempunyai tingkat signifikansi sebesar 0.063 yang melebihi 0.05 . Hasil pengujian ini tidak sejalan dengan Abdullah dan Ismail (2016) yang mengatakan leverage meningkatkan kemungkinan earnings management. Namun penelitian ini sejalan dengan Elfira (2014) yang mengatakan leverage tidak berpengaruh signifikan dengan AA. Hal ini disebabkan karena rata-rata perusahaan memiliki leverage yang rendah, yaitu rata-rata 19.397\%, dalam arti perusahaan mampu membayar hutang yang dipakai untuk membiayai aset perusahaan, maka manajer tidak termotivasi untuk melakukan praktek earnings management. Ini disebabkan karena perusahaan tidak memerlukan perlakuan-perlakuan yang akan membantu perusahaan pada situasi tertentu. Perusahaan dalam keadaan yang baik atau 
Hubungan Komplementer Antara Manajemen Puncak Perempuan Dan Literasi Keuangan Tehadap Earnings Management Pada Perusahaan Yang Terdaftar Di BEI Periode 2015

aman dan mampu untuk membayar hutang yang dipakai untuk membayai aset perusahaan (Elfira, 2014).

Menurut Meek et al (2007) perusahaan yang sedang mengalami pertumbuhan tinggi biasanya akan kurang transparan dan mungkin mempunyai peluang yang lebih besar dalam melakukan earnings management. Namun variabel GROWTH terbukti tidak dapat berpengaruh signifikan terhadap AA yaitu dengan mempunyai tingkat signifikansi sebesar 0.287 yang melebihi 0.05. Hasil pengujian ini sejalan dengan Savitri (2014) yang mengatakan growth tidak mempunyai pengaruh yang signifikan terhadap earnings management.

Peneliti melakukan uji regresi kembali dengan variabel WBD, WBC, WAC yang digabung menjadi variabel WD (Woman Director) dan variabel WBDFL, WBCFL, WACFL digabung menjadi variabel WDFL (Woman Director Financial Literacy). Masing-masing variabel menggunakan dummy sehingga apabila terdapat perempuan dalam posisi manajemen puncak (WBD, WBC, WAC) maka WD bernilai satu, dan apabila terdapat perempuan yang literasi keuangan dalam posisi manajemen puncak (WBD, WBC, WAC) maka WDFL bernilai satu. Pengujian kembali ini dilaukan untuk mengetahui apabila variabel manajemen puncak perempuan dan manajemen puncak perempuan yang literasi keuangan digabung apakah dapat memberi pengaruh terhadap earnings management. Berikut ini merupakan model regresi yang digunakan:

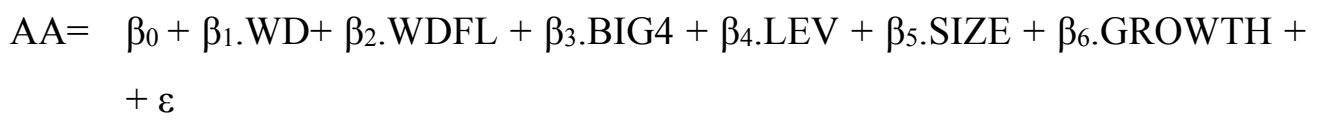

Hasil regresi menunjukkan bahwa variabel WD, dan WDFL memiliki tingkat signifikan sebesar 0.586 dan 0.867 yang melebihi 0.05 . Ini menunjukkan bahwa WD dan WDFL tidak dapat berpengaruh signifikan terhadap earnings management yang sesuai dengan uji pada model regresi sebelumnya. Hasil regresi ini dapat dilihat pada tabel 4.

\section{KESIMPULAN}

Penelitian ini menguji pengaruh manajemen puncak perempuan dan manajemen puncak perempuan yang literasi keuangan dengan pengurangan earnings management. Berdasarkan hasil penelitian dan analisis data yang telah dilakukan oleh peneliti mengenai pengujian hipotesis, maka peneliti dapat menyimpulkan bahwa keberadaan perempuan dan perempuan yang literasi keuangan dalam posisi manajemen puncak dalam perusahaan yang 
Hubungan Komplementer Antara Manajemen Puncak Perempuan Dan Literasi Keuangan Tehadap Earnings Management Pada Perusahaan Yang Terdaftar Di BEI Periode 2015

terdaftar di Bursa Efek Indonesia pada tahun 2015 tidak memiliki pengaruh terhadap earnings management.

Dalam proses pengerjaan dan penyelesaian skripsi ini, peneliti dihadapkan pada beberapa keterbatasan dan kendala yang diharapkan tidak terjadi pada penelitian selanjutnya. Keterbatasan dan kendala yang dihadapi oleh peneliti terkait penelitian ini adalah sebagai berikut yaitu terdapat eterbatasan peneliti untuk memperoleh data tentang riwayat pendidikan dan pengalaman bekerja dari dewan komisaris, dewan komisaris, dan komite audit. Data tersebut digunakan untuk menentukan manajemen puncak perempuan tersebut literasi keuangan. Jika perusahaan tidak menampilkan riwayat pendidikan dan pengalaman bekerja dalam laporan tahunan perusahaannya, maka peneliti menganggap manajemen puncak perempuan tersebut tidak literasi keuangan.

Keterbatasan yang lain adalah beberapa perusahaan yang gender dari manajemen puncaknya tidak dapat ditentukan oleh peneliti dan beberapa data perusahaan yang tudak lengkap sehingga harus dihapus dari sampel. Sehingga data yang diolah dalam penelitian ini tidak mewakili kondisi seluruh perusahaan yang terdaftar di Bursa Efek Indonesia pada tahun 2015. Selain itu peneliti menggunakan periode yang pedek yaitu hanya pada tahun 2015 saja.

Berdasarkan keterbatasan studi yang telah dijelaskan, maka peneliti memberikan beberapa rekomendasi untuk penelitian selanjutnya agar lebih meningkatkan kualitas

penelitian yang telah ada, yaitu menambah sumber data yang lain untuk menentukan literasi keuangan dan gender dari manajemen puncak perusahaan, tidak hanya dari website dan laporan yang dipublikasikan oleh perusahaan. Penelitian selanjutnya sebaiknya menambah periode penelitian dengan lebih panjang sehingga dapat membandingkan pengaruh manajemen puncak perempuan dan manajemen puncak perempuan yang literasi keuangan terhadap earnings management dari tahun ke tahun.

\section{DAFTAR PUSTAKA}

Abdullah, S.N., K.N.I.K. Ismail. 2016. Women directors, family ownership and earnings management in Malaysia.Asian Review of Accounting, Vol 24, No.4, pp 525-550.

Adams, R. B., dan D. Ferreira. 2009. Women in The Boardroom and Theory Impact on Governance and Performance. Journal of Financial Economics, Vol. 94, pp 291-309. 
Hubungan Komplementer Antara Manajemen Puncak Perempuan Dan Literasi Keuangan Tehadap Earnings Management Pada Perusahaan Yang Terdaftar Di BEI Periode 2015

Ambrose, M.L., M. Schminke. 1999. Sex Differences in Business Ethics: The Importance of Perceptions. Journals of Managerial Issues, Vol.11, No.4, pp 454-474.

Chen, I., I. Gavious. 2016. Complementary relationship between female directors and Financial Literacy in deterring earnings management: The Case of High Technology Firms. Advances in Accounting, incorporating Advances in International Accounting, Vol. 35, pp 114-124.

Dieleman, M. dan M. Aishwarya. 2012. Indonesia Boardroom Diversity Report 2012. Singapore: Centre for Governance, Institutions \& Organisations NUS Business School.

Dieleman, M., M. Ibrahim, M. Qian, dan V. Lim. 2015. Diversity Matters - Adding Colour to Board in APAC. Singapore: Centre for Governance, Institutions \& Organisations NUS Business School.

Elfira, Anisa. 2014. Pengaruh Kompensasi Bonus dan Leverage Terhadap Manajemen Laba. Program Studi Akuntansi Fakultas Ekonomi Universitas Negeri Padang, Indonesia, Vol 2, No 2 .

Fondas, N., dan S. Sassalos. 2000. A different voice in the boardroom: How the presence of women directors affects board influence over management. Global Focus, Vol. 12, pp $13-22$

Gavious, I., E. Segev, dan R. Yosef. 2011. Female Directors and Earnings Management in High Technology Firms. International Small Business Journal, Vol 24 No.1, pp 4-32.

Grant Thorton. 2017. Women in Business. https://www.grantthornton.global/globalassets/1.member firms/global/insights/article-pdfs/2017/grant-thornton women-inbusiness 2017-report.pdf (diunduh tanggal 19 Juni 2017).

Hilman, A.J., C. Shropshire, dan A.A. Cannella. 2007. Organizational Predictors of Women on Corporate Boards. Academy of Management Journal, Vol. 50 No.4, pp 941-952.

Huston, S.J. 2010. Measuring Financial Literacy. Journals of Customer Affairs, Vol.44, No.2,pp 296-316.

Komite Nasional Kebijakan Governance (KNKG). 2006. Pedoman Umum Good Corporate Governance Indonesia. http://berita.knkg-indonesia.org/2016/11/pelaksanaan-goodgovernance-di-indonesia.html (diunduh tanggal 19 Juni 2017).

Kompas.com. 18 Mei 2017. Kerja Keras dan Tak Pernah Cuti Selama 27 Tahun, Wanita Ini Capai Puncak Karier. http://biz.kompas.com/read/2017/05/18/153000428/kerja.keras.dan.tak.pernah.cuti.sel ama.27.tahun.wanita.ini.capai.puncak.karier (diakses pada 3 Juni 2017).

Konrad, Alison M., Vicki Kramer, dan Sumru Erkut. 2008. The Impact of Three or More Women on Corporate Boards.Organizational Dyanamic, Vol.37, No.2. 
Hubungan Komplementer Antara Manajemen Puncak Perempuan Dan Literasi Keuangan Tehadap Earnings Management Pada Perusahaan Yang Terdaftar Di BEI Periode 2015

Luhgiatno. 2010. Analisis Pengaruh Kualitas Audit Terhadap Manajemen Laba Studi pada Perusahaan yang Melakukan IPO di Indonesia. Fokus Ekonomi, Vol. 5, No.2.

Savitri, Enni. 2014. Analisis Pengaruh Leverage dan Siklus Hidup Terhadap Manajemen Laba pada Perusahaan Real Estate dan Property yang Terdaftar di Bursa Efek Indonesia. Jurnal Akuntansi, Vol.3, No.1, pp 72-89.

Schrand, C.M., dan S.L.C. Zechman. 2012. Executive Overcofidence and The Slippery Slope to Financial Misreporting. Journal of Accounting and Economics, Vo.53, No.1-2, pp 311-329.

Xie, B., W. Davidson, dan P. Dadalt. 2003. Earnings management and coporate governance: The roles of the board and the audit committee. Journal of Corporate Finance, Vol.9, pp 295-316. 